\title{
The Reception of Charles S. Peirce in Denmark
}

\section{Bent Sørensen and Torkild Thellefsen}

\section{OpenEdition}

\section{Journals}

Electronic version

URL: http://journals.openedition.org/ejpap/498

DOI: 10.4000/ejpap.498

ISSN: 2036-4091

\section{Publisher}

Associazione Pragma

\section{Electronic reference}

Bent Sørensen and Torkild Thellefsen, «The Reception of Charles S. Peirce in Denmark», European Journal of Pragmatism and American Philosophy [Online], VI-1 | 2014, Online since 08 July 2014 connection on 17 March 2020. URL : http://journals.openedition.org/ejpap/498 ; DOI : https://doi.org/ 10.4000/ejpap.498

This text was automatically generated on 17 March 2020.

\section{c)}

Author retains copyright and grants the European Journal of Pragmatism and American Philosophy right of first publication with the work simultaneously licensed under a Creative Commons AttributionNonCommercial-NoDerivatives 4.0 International License. 


\title{
The Reception of Charles S. Peirce in Denmark
}

\author{
Bent Sørensen and Torkild Thellefsen
}

\section{Setting the Scene}

1 Despite of or maybe because of much activity and numerous Danish scholars working with Peircean ideas, concepts, and methodology, there does not exist one single current concerning the reception of Peirce in Denmark. However, it seems safe to assume that the majority of Danish scholars working with Peirce - in one way or the other - initially came and to some degree still come to Peirce with an interest in his doctrine of signs or semeiotic, and then maybe from there, not seldom, will also investigate other parts of Peirce's intriguing and comprehensive system of thought. Furthermore, most Danish scholars working with Peirce are exactly "working with Peirce," meaning that they come from a given area of research where they - theoretically / methodologically / empirically - establish a Peircean perspective. Or put in another way: strict exegesis of key texts within Peirce's authorship was - so far - not in the forefront in the Danish reception of Peirce, rather, the focus is on what we can call "Peirce applied" using a broad conception of what it means to "apply" Peirce.

\section{The First Beginnings}

2 It is, of course, always difficult, if not impossible, to date the beginning of the introduction of a thinker within a nationally delimited area, if anywhere, but, when looking back from the beginning of the 80s until today, certain names and groups of scholars with different affiliations and research interests, as well as certain events, seem prominent and point towards how Peirce has been received, interpreted and used in Denmark. The first Danish scholar to cultivate a strong interest in Peirce was probably the physicist Peder Voetmann Christiansen at Roskilde University Center who took interest in Peirce's cosmology and theory of science in order to address 
fundamental issues in quantum mechanics. He translated Peirce's first set of Monist papers under the title of Mursten og Mørtel til en Metafysik (Bricks and Mortar for a Metaphysics), IMFUFA working paper $n^{\circ} .169$ (1988), later published as Kosmologi og metafysik (below) and strongly contributed to the spread of Peircean ideas in Danish academia.

When Danish semiotics saw a renaissance in the 1980s and the 1990s, Peirce was also "a significant part of that." Major figures in the development were the philologist Per Aage Brandt and the literary scholar Jørgen Dines Johansen, who both founded their own school and published extensively internationally. Brandt arranged (together with Anne Marie Dinesen) Seminar i Almen Semiotik (Seminars concerning General Semiotics), founded the journal Almen Semiotik (General Semiotics) - the first issue was a special issue on Peirce - and established "Center for Semiotik" ("Center for Semiotics") - and thereby making Peirce known to a broader Danish audience of students and scholars coming from very different areas of studies and research. Brandt published numerous of articles and books going more and more in the direction of formulating a "Cognitive Semiotics" also making a recourse to Peircean concepts such as sign, diagrammatic and iconic models, types of signs - and seeing processes of thought as processes of inference within a realist epistemology. In 1982 Dines Johansen went to Indianapolis to study the manuscripts of Peirce at The Peirce Edition Project. When Dines Johansen returned to Denmark he published articles and books inducing the readers to think semiotics with Peirce for example in Prolegomena to a Semiotic Theory of Text Interpretation (1986) and Dialogic semiosis. An Essay of signs and Meaning (1993). Dines Johansen was aiming to develop a semio-pragmatic theory of literature and a semiotics of the production, transmission, and interpretation of signs in human communication. Concerning the latter, Dines Johansen clarified the presuppositions of dialogic communication according to Peirce dealing with Peirce's speculative grammar, rhetoric, fixation of beliefs and the concept of community, and thereby Dines Johansen could introduce his own Peircean inspired "Semiotic pyramid."

\section{Introducing Peirce}

4 The 1980s and the 1990s also witnessed introductions to Peirce in Danish. Poul Lübcke edited Videnskab og sprog (1982) (Science and Language) about the Anglo Saxon Philosophy and one of the contributions by Niels Christian Stefansen placed Peirce in the pragmatist tradition describing his pragmatic maxim, concepts of truth and reality, semeiotic, theory of inquiry, and metaphysics. Furthermore, Anne Marie Dinesen published C.S. Peirce-feenomenologi, semiotik og logik (1991) (C. S. Peirce-phenomenology, semiotics, and logic), Keld Gall Jørgensen published Semiotik (1993) (Semiotics), and Dines Johansen and Svend Erik Larsen published Tegn $i$ brug (1994) (Signs in use). Finally, two selections of Peirce texts were translated into Danish Semiotik og pragmatisme (1994) (Semiotics and Pragmatism) edited by Frederik Stjernfelt and Anne Marie Dinesen and Kosmologi og metafysik (1996) (Cosmology and metaphysics) edited by Peder Voetmann Christiansen. These publications in the 1990s marked an increased interest in Peirce, and some of his texts now began to find their way into the curricula of the philosophy departments, and Peircean concepts - such as infinite semiosis, icon-index-symbol, abduction and pragmatism - could also be seen, more and more, in the tool boxes of Danish students and scholars coming from different humanistic disciplines e.g. 
literature theory, cultural studies, communication, and media and advertising research.

\section{The Copenhagen School of Biosemiotics, Cyber- Semiotics, and Diagrammatology}

During the 1980s, the 1990s, and the 2000s the "Copenhagen School of BioSemiotics" has committed itself to develop a "Semiotics of Nature" ranging from the lowest levels of sign processes in simple organisms to the cognitive and social and communicative behavior of animals - and thereby crossing the nature-culture barrier. Hence, theorists like biochemist Jesper Hoffmeyer, biologist Claus Emmeche, cyber-semiotician Søren Brier, and polyhistor Frederik Stjernfelt have - in one way or the other - worked their ways into a transdisciplinary framework in order to explain how all the phenomena of inherent meaning and signification in living nature have emerged in the universe - a universe which, in its very beginning, was chaotic and devoid of meaning and processes of signification. Following Peirce (and Thomas Sebeok) the "Bio-Semioticians" understand life and semiosis as being co-extensive and inspired by Peirce's writings on e.g. the triadic sign, mind, qualia, feeling, habit formation, evolutionary love, objective idealism, spontaneity and anti-determinism, they try to find and explain Signs of Meaning in the Universe (1996) as is the title of Hoffmeyers landmark volume. In the Cyber-semiotics of Brier - e.g. Cybernetics: Why Information is not Enough (2008) - a transdisciplinary bio-psycho-social framework for understanding perception, signification, cognition, and communication, perhaps, the strongest influence from Peirce is found, and Brier integrates the Peircean point of view that the substance of reality is continuous, signs and regularities have real being, and it is impossible to remove the mental and the emotional from basic reality. Besides Stjernfelt's participation in the Copenhangen School of Biosemiotics it should also be mentioned that he has developed a "Theory of Diagrammatology" based on the mature Peirce (as well as Husserl). Stjernfelt investigates the role of diagrams in thought and knowledge as a centerpiece of epistemology - the Peircean diagrams allows for observation and experimentation with ideal structures and objects. Stjernfelt focuses on three regional areas of research within semiotics: biosemiotics, picture analysis and literature, and his diagrammatological approach leave the traditional relativism and culturalism behind, hence formulating a Peircean realist position. Stjernfelt's theory is most fully developed in Diagrammatology. An Investigation on the Borderlines of Phenomenology, Ontology and Semiotics (2007). In 2014, he published Natural Propositions. The Actuality of Peirce's Doctrine of Dicisigns, arguing that Peirce's theory of propositions differs significantly from mainstream philosophy of logic and that it allows for propositions transgressing the medium of language, embracing pictures, diagrams, gesture etc. on the one hand and non-human communication and cognition on the other.

\section{Library and Information Science, Advertising Research, and Branding}

6 From the 1990s and onwards Peirce's thought has also been found relevant within parts of Library and Information Science (LIS) in Denmark. Brier's book Information er sølv- 
Om muligheden for en pragmatisk informationsvidenskab baseret på anden ordens kybernetik, semiotik og sprogspilsteori (1994) (Information is silver - concerning the possibility of creating a pragmatic information science based on second order cybernetics, semiotics and language game theory) marked the beginning of this new field of application, suggesting a transdisciplinary framework in which a Peircean concept of information, encompassing nature and culture, is rooted in a realistic ontology and evolutionary metaphysics. Building partly upon the works of Brier, Torkild Thellefsen, Martin Thellefsen, and Bent Sørensen have developed a Peircean concept of information primarily focusing on different cognitive aspects. Seeking direction from Peirce's phenomenological categories, speculative grammar, rhetoric, and realistic epistemology/ontology, Thellefsen and Sørensen came to understand information in relation to meaning creation and communication and define the concept within the triad emotioninformation-cognition, also pointing towards its relevance for the system,- user,- and domain oriented perspectives within LIS. Torkild Thellefsen's book Fundamental Signs and Significance-Effects. A Semeiotic Outline of Fundamental Signs, Significance-Effects, Knowledge Profiling and Their Use in Knowledge Organization and Branding (2010) lays bare the theoretical presuppositions. Another, perhaps more surprising, area of application of Peircean ideas within Danish Academia is marketing and consumer research. Hence, from the beginning of the 2000s Peirce's semeiotic has been instrumental in understanding advertising and branding. Using Peirce's concept of consciousness, interpretant, and three modes of inference, Christian Andersen, Bent Sørensen, and Christian Jantzen have dealt with the structure of print advertisements indicating which signs functions to potentiate different effects of comprehension within the perceiver. Concerning brands and the process of branding Torkild Thellefsen and Bent Sørensen (also in collaboration with Marcel Danesi) have introduced the Peircean concepts of "Cognitive Branding" and the "Value Profile" in order to understand how the meaning of life style values become embedded in products and thereby influence people to make their purchase. The two concepts are anchored theoretically in Peirce's pragmaticism including his classification of the interpretants, the idea of habit and habit formation, and the maxim of meaningfulness, which direct the research towards four (inter)related perspectives: i) regarding branding as a process of meaning creation; ii) regarding a shared memory between brand users; iii) regarding the cognitive attention of brand users; and iv) regarding branding communities. In the pragmatic terminology of Peirce a brand is a symbol representing, upholding, and communicating values and a shared memory in a particular cultural setting (a universe of discourse, based on collateral experience) to its interpreters.

\section{Peirce's Metaphysics and His Remarks on Metaphor}

7 The metaphysics of Peirce has also attracted the interest of Danish scholars during the 2000s. Søren Brier, Bent Sørensen, and Torkild Thellefsen have examined parts of Peirce's explanation of the main features of the universe such as chance, growth, laws of nature and mind and feeling in order to understand the thorough-going evolutionary character of his cosmology. Furthermore, building on the Peirce-scholar Father Vincent Potter (1929-1994), the authors have argued for a close connection between Peirce's concept of Summum Bonum (the highest good) and the aesthetical influence on the growth of ideas as an important aspect of creative processes. 
Peirce had no theory of metaphor and he provided only a few remarks concerning the topic. However, Bent Sørensen and Torkild Thellefsen have worked with "the metaphor in a Peircean perspective." According to the authors Peirce had a "modern view on metaphor" as a semeiotic mechanism (a hypoicon) which is fundamental to thought and consciousness. Sørensen and Thellefsen try to develop the relation between metaphor and cognition and they understand the Peircean metaphor as rooted in the abductive mode of inference - hence, it is part of an intricate relation between experience, body, sign, and a guessing instinct as a semeiotic mechanism which can convey new insights.

\section{The Reception of Peirce in the Future}

It is now more than three decades ago since Peirce was first introduced in Denmark. The reception of Peirce has been manifold showing a wide range of areas of relevance and application - from general semiotics, over literature theory, Biosemiotics, Cybernetics, epistemology of science, Library and Information science to Marketing and Consumer research. Trying to foresee Peirce's relevance for the future Danish research and scholarship is not necessarily easy - but we still believe that the prospects for applying Peirce should be legion - he was a true polyhistor with a mind open towards new, interesting possibilities.

We would like to thank Dr. of Philosophy, Professor Frederik Stjernfelt for his constructive comments.

\section{BIBLIOGRAPHY}

BRIER S., (1994), Information er sølv - Om muligheden for en pragmatisk informationsvidenskab baseret på anden ordens kybernetik, semiotik og sprogspilsteori, Aalborg, Forlaget Biblioteksarbejde.

BRIER S., (2008), “Cybernetics: Why Information is not Enough,” Toronto Studies in Semiotics and Communication, Toronto, Toronto University Press.

DINES JOHANSEN J., (1985), “Prolegomena to a Semiotic Theory of Text Interpretation," Semiotica 57 (3/4), 225-288.

DINES JOHANSEN J., (1993), Dialogic semiosis. An Essay of signs and Meaning, Bloomington and Indianapolis, Indiana University Press.

DINES JOHANSEN J. \& L. SVEND ERIK, (1994), Tegn i brug, Bagsværd, Forlaget Amanda.

DINESEN A. M., (1991), C. S. Peirce - feenomenologi, semiotik og logik, Aalborg, Nordisk sommeruniversitet.

HOFFMEYER J., (1996), Signs of Meaning in the Universe, Bloomington and Indianapolis, Indiana University Press.

LÜBCKE P., (1982), Vor tids filosofi - Videnskab og sprog, København, Politiken. 
PEIRCE C. S., (1994), Semiotik og pragmatisme, Oversat og redigeret af Peder Voetman Christiansen, København, Gyldendal.

PEIRCE C. S., (1996), Kosmologi og Metafysik, Redigeret af Frederik Stjernfelt - Anne Marie Dinesen, København, Gyldendal.

STJERNFELT F., (2007), Diagrammatology. An Investigation on the Borderlines of Phenomenology, Ontology, and Semiotics, Dordrecht, Springer.

STJERnfelt F., (2014), Natural Propositions. The Actuality of Peirce's Doctrine of Dicisigns, Boston, Docent Press.

SøRENSEN B. \& T. THELLEFSEN, (2006), "Metaphor, concept formation, and esthetic semeiosis in a Peircean Perspective," Semiotica 161 (1/4), 199-213.

SøRENSEN B., THELLEFSEN T. \& M. MORTEN, (2007), "Some Comments regarding Metaphor and Cognition in a Peircean Perspective," Transactions of the Charles S. Peirce Society 43 (3), 543-562. SøRENSEN B., THELLEFSEN T. \& B. søRen, (2012), "Mind, Matter, and Evolution - An Outline of C. S. Peirces Evolutionary Cosmogony," Cybernetics \& Human Knowing 19 (1), 95-120.

TORKILD T., (2010), A Semiotic Outline of Significance-effect, Fundamental Sign and Knowledge Profiling and Their Use in Knowledge Organization and Branding, Saarbrücken, VDM Verlag.

voETMAN P., (1988), "Mursten og mørtel til en metafysik (Bricks and Mortar for a Metaphysics)," IMFUFA, Working Paper $n^{\circ} .169$.

\section{AUTHORS}

\section{BENT SøRENSEN}

Denmark

legisign[at]gmail.com

TORKILD THELLEFSEN

Københavns Universitet, Denmark

thellefsen[at]gmail.com 